\title{
Consumer Independence Against the Decisions to Buy Online Products
}

\author{
Meiliyah Ariani* \\ Fakultas Ekonomi dan Bisnis \\ Universitas Prof. Dr. Moestopo (Beragama) \\ Jakarta, Indonesia \\ *meiliyah_ariani@dsn.moestopo.ac.id
}

\author{
Zulhawati Zulhawati \\ Fakultas Bisnis, Psikologi dan Komunikasi \\ Universitas Teknologi Yogyakarta \\ Yogyakarta, Indonesia \\ zulhawati@uty.ac.id
}

\author{
Panji Putranto \\ Fakultas Ekonomi dan Bisnis \\ Universitas Mercubuana \\ Jakarta, Indonesia \\ panji.putranto@mercubuana.ac.id
}

\begin{abstract}
The aim of this study was to examine the effects of public policy, technical standards and organizational systems of e-commerce to online purchasing decisions. Public policy of ecommerce is measured by law / taxes \& privacy issues, speechfree and domain names. The technical standards of e-commerce are measured by documents, security / network protocols and payment systems. The organization's system of e-commerce is measured with partners, competitors and associations \& government services. Online purchasing decisions are measured by problem identification, information search, alternative evaluation, purchasing decisions and post purchase behavior. The analysis model used in hypothesis testing is multiple regression analysis with the help of SPSS version 20 program. This analysis is based on valid questionnaires from 120 respondents collected from e-commerce consumers in South Jakarta. The results of this study indicate that public policy, technical standards and organizational systems of e-commerce have a positive and significant effect on online purchasing decisions.
\end{abstract}

Keywords: independence, public policy, technical standards, organizational systems, e-commerce, online purchasing decisions

\section{INTRODUCTION}

The process of globalization which is very fast accompanied by the development of information and communication technology has brought significant changes to human life. In the process of globalization is the limited boundaries and barriers, exchange of information and communication can be easily and quickly obtained by each individual wherever and whenever. The development of modern technology has implications for changes in performance for human life, and technology that is a winner and is growing rapidly is a technology that serves and accommodates humans as a whole rather than just sophisticated technology created for sophistication itself [1].

One embodiment of the development of information and communication technology is the internet network. Internet technology has given a large enough role to the business, so that business and economic development is often a major concern. This development which then creates opportunities for creative economic actors to see new business opportunities. Where the current economic transactions are no longer carried out directly, but rather indirectly. From the development of information and communication technology, new ways are formed to access new markets through electronic commerce or what is commonly called e-commerce.

In the past 5 years, e-commerce in Indonesia has proven its glory. Even Indonesia's e-commerce market has the potential to be the largest in Southeast Asia, because it is considered as the country with the strongest mobile penetration [2]. But in reality, until now there are still often threats and problems related to e-commerce. This crime refers to cybercrime, for example, a case of piracy on an e-commerce site, an online ticket that was recently revealed, then several cases of fraud that occurred on the Lazada ID site. The case of account hijacking caused burglary credit cards belonging to consumers for transactions that were not carried out by consumers, it turns out cases like this have happened to several consumers and again occur at Lazada ID.

The Objectives Advanced Research are (1) to identify and explain the effect of public policy of e-commerce on purchasing decisions online; (2) to find out and explain the effect of $e$-commerce technical standards on online purchasing decisions; (3) to know and explain the influence of $e$-commerce organization systems on online purchasing decisions. 


\section{LITERATURE REVIEW}

\section{A. E-Commerce}

E-commerce is part of e-business, where the scope of ebusiness is broader, not only for business but also includes collaborating with business partners, customer service, job vacancies and others. In addition to the www network technology, e-commerce also requires database or database technology, e-mail and other forms of non-computer technology such as goods delivery systems and payment tools for e-commerce

Electronic commerce or commonly abbreviated as ecommerce is electronic commerce that includes the process of buying, selling, transferring, exchanging products, services or information through a computer network [3].

\section{B. Online Purchase Decision (Y)}

Purchasing decision is a selection of two or more alternative choices that result in a decision to buy or not buy, this means that alternative choices must be available when consumers will make a decision. In other words, consumers who want to make choices must make choices from various alternatives. If alternative choices do not exist, then actions taken without these choices cannot be said to make a decision [4].

\section{E-Commerce Public Policy (X1)}

Public policy as a series of actions proposed by a person, group or government in a particular environment, with the threats and opportunities that exist [5]. The proposed policy is intended to exploit the potential while overcoming existing obstacles in order to achieve certain goals. The pillars of public policy on e-commerce consist of tax, legal and privacy issues, free speech and domain names [6].

\section{E-Commerce Technical Standards (X2)}

Special technical standards of e-business, where ecommerce is part of e-business, is to facilitate the exchange of data between one company with another company [7]. This can mean that the technical standards that exist in e-commerce function as a facilitator to handle the data exchange process between consumers and e-commerce parties. Technical standards are considered to be one of the four main areas as a pillar supporting e-commerce, where the technical standard pillars consist of documents, security and network protocols, and payment systems [6].

\section{E. E-Commerce Organization System (X3)}

E-Commerce Organization System an organization is a social unit of a group of people who interact with each other according to a certain pattern so that each member of the organization has their respective functions and duties, as a unit that has certain goals and has limits clear boundaries, so they can be separated [8].

E-commerce if viewed from the perspective of collaboration is a facilitator that can be used to enable the collaboration process in an organization both between organizations and between organizations [9]. This can be interpreted that e-commerce is considered as a forum between organizations in forming business collaboration. E-commerce must work with several related organizations such as the bank in handling payments, and the logistics in handling the delivery of goods. Good cooperation between organizations will build trust and comfort for consumers to transaction online.

\section{METHODS}

\section{A. Hypothesis Development}

This section presents hypothesis development.

H1: Public policies of e-commerce influence on online purchasing decisions.

$\mathrm{H}$ 2: E-commerce technical standards influence online purchasing decisions.

H3: The e-commerce organization system influences online purchasing decisions.

H4: Public policies, technical standards and e- commerce organization systems influence online purchasing decisions.

\section{B. Model and Research Design}

Model and design of this research were to obtain data on the variables that influence public policy, technical standards and the organizational system of e-commerce on purchasing decisions online. This type of research used in this research is descriptive research with a quantitative approach

Research quantitatively based on the philosophy of positivism, is used to examine the population or a particular sample, data collection using research instruments, quantitative data analysis / statistics, with the aim to test the hypothesis that has been set [10].

The population in this research is the people who live in South Jakarta. The size or number of samples that will be used in this study is 120 respondents. The sampling technique used in this study is the quota sampling method.

\section{Research Variables}

The variables used in this study consist of 2 (two) variables:

- Independent variables are used in this research to include public policies, technical standards, and organizational systems.

- Dependent variable is used in this study to include online purchasing decisions.

\section{Data Analysis Method}

Data analysis methods used in this study are:

1) Descriptive statistics test [11].

2) Data quality test, consisting of: (1) Validity test and (2) Reliability Test [12].

3) Classic assumption test, consisting of: (1) Normality test, (2) Multycollinearity test and (3) heteroscedasticity

4) Hypothesis test: 


\section{F Statistical Test Results (Simultaneous Test)}

- Multiple Regression Analysis:

- Statistical Test F (Simultaneous Test)

- $\quad$ T Statistical Test (Partial Test)

\section{5) Determination coefficient test}

\section{RESULTS AND DISCUSSION}

\section{A. Descriptive Statistics Results}

From the descriptive statistical analysis, the results are obtained as presented in the following table:

TABLE I. DESCRIPTIVE STATISTICS

\begin{tabular}{|c|c|c|c|c|c|c|c|}
\hline & N & Min & Max & Sum & $\begin{array}{c}\text { The } \\
\text { mean }\end{array}$ & $\begin{array}{c}\text { Std. } \\
\text { Deviation }\end{array}$ & Variance \\
\hline $\begin{array}{c}\text { E-Commerce } \\
\text { Public Policy }\left(X_{1}\right)\end{array}$ & 120 & $\begin{array}{l}10: 00 \\
\mathrm{PM}\end{array}$ & 42.00 & 4002.00 & 33.3500 & 3.92503 & 15,406 \\
\hline $\begin{array}{c}\text { E-Commerce } \\
\text { Technical } \\
\text { Standards }\left(\boldsymbol{X}_{2}\right)\end{array}$ & 120 & 27.00 & 52.00 & 4972.00 & 41,4333 & 4.15808 & 17290 \\
\hline $\begin{array}{c}\text { E-Commerce } \\
\text { Organizational } \\
\text { System }\left(\boldsymbol{X}_{3}\right)\end{array}$ & 120 & 24.00 & 44.00 & 4327.00 & 36.0583 & 3.40858 & 11,618 \\
\hline $\begin{array}{c}\text { Online Purchase } \\
\text { Decision }(\boldsymbol{Y})\end{array}$ & 120 & 48.00 & 80.00 & 8130.00 & 67,7500 & 5.69424 & 32424 \\
\hline Valid $\boldsymbol{N}($ listwise $)$ & 120 & & & & & & \\
\hline
\end{tabular}

Based on Statistical analysis descriptive shown in Table 1, the value of the standard deviation of the overall variable figures show that 1 ore smaller than

the average value, it shows good results, because the standard deviation which is a deviation of the data is smaller than the average.

\section{B. Multiple Regression Analysis}

The results of the multiple regression analysis in this study are presented in the following table:

TABLE II. DOUBLE REGRESSION RESULTS

\begin{tabular}{|c|c|c|}
\hline \multirow{2}{*}{ Model } & \multicolumn{2}{|c|}{ Unstandardized Coefficients } \\
\cline { 2 - 3 } & $\boldsymbol{B}$ & Std. Error \\
\hline (Constant) & 17,270 & 4,059 \\
\hline E-Commerce Public Policy & .469 & .119 \\
\hline E-Commerce Technical Standards & .486 & .117 \\
\hline E-Commerce Organization System & .408 & .113 \\
\hline
\end{tabular}

According to the table 2 at the top, then the regression equation can be obtained as follows:

Y (Purchasing Decisions Online $)=17.270$ (constants) + 0.469 (Public Policy) + 0.486 (Technical Standard) +0.408 (Organization System) + error.
TABLE III. ANOVA VARIANS ANALYSIS RESULTS

\begin{tabular}{|c|c|c|c|c|c|}
\hline Model & Sum of Squares & Df & Mean Square & F & Sig. \\
\hline Regression & 2301,683 & 3 & 767,228 & 57,167 & $.000^{\text {b }}$ \\
Residual & 1556,817 & 116 & 13,421 & & \\
\hline Total & 3858,500 & 119 & & & \\
\hline
\end{tabular}

a. Dependent Variable: Decision to Buy Online b. Predictors: (Constant), e-Commerce Organization System, e-Commerce Public Policy, eCommerce Technical Standards

Based on $\mathrm{f}$ analysis test in table 3 above, it is known that the regression coefficient on each independent variable is positive, so it can be interpreted that the variables $\mathrm{X} 1, \mathrm{X} 2$ and $\mathrm{X} 3$ together have a positive effect on $\mathrm{Y}$.

\section{T Statistical Test Results (Partial Test)}

TABle IV. Static Test Results T (Partial TeSt)

\begin{tabular}{|c|c|c|c|c|c|}
\hline \multirow[t]{2}{*}{ Model } & \multicolumn{2}{|c|}{$\begin{array}{c}\text { Unstandardized } \\
\text { Coefficients }\end{array}$} & \multirow{2}{*}{$\begin{array}{c}\begin{array}{c}\text { Standardized } \\
\text { Coefficients }\end{array} \\
\text { Beta }\end{array}$} & \multirow[t]{2}{*}{$\mathbf{t}$} & \multirow[t]{2}{*}{ Sig. } \\
\hline & B & Std. Error & & & \\
\hline (Constant) & 17,270 & 4,059 & & 4,255 & .000 \\
\hline (X1) & .469 & .119 & .324 & 3,930 & .000 \\
\hline (X2) & .486 & .117 & .355 & 4,157 & .000 \\
\hline (X3) & .408 & .113 & .244 & 3,604 & .000 \\
\hline
\end{tabular}

a. Dependent Variable: Decision to Buy Online

Based on $\mathrm{t}$ analysis test in table 4 above, it is known that the coefficients of the variables X 1 (B) is equal to $0.469, \mathrm{X} 2$ (B) is equal to 0.486 and $\mathrm{X} 3$ is equal to 0.408 there results a positive value so that it can be said that $\mathrm{X} 1, \mathrm{X} 2$ and $\mathrm{X} 3$ positive effect to $\mathrm{Y}$.

\section{E. Determination Coefficient Test Results}

Determination Coefficient

\begin{tabular}{|c|c|c|c|c|}
\hline \multicolumn{5}{|c|}{ Summary Model ${ }^{\text {b }}$} \\
\hline Model & $\bar{R}$ & R Square & Adjusted R Square & $\begin{array}{c}\text { Std. Error of the } \\
\text { Estimate }\end{array}$ \\
\hline & $.772^{a}$ & 597 & 586 & 3,66345 \\
\hline
\end{tabular}

b. Dependent Variable: Online Purchasing Decisions

Based on the test results of coefficient determination in Table 5 above, the value of the coefficient of determination ( $R$ 2) of 0.597 means that the relative contribution given by a combination of variables $\mathrm{X} 1, \mathrm{X} 2$ and $\mathrm{X} 3$ to $\mathrm{Y}$ is equal to $59.7 \%$, while the rest influenced by other variables not examined in this study.

\section{F. Discussion of Results Analysis}

1) Effect of e-Commerce public policy on online purchasing decisions: Based on the analysis on policy variable public policy e-commerce measured by: the legal / tax and the issue of privacy, free speech, as well as the domain name, stated that there are positive and significant influences impact on the decision to buy online products. 
cooperating with parties such as banks and reliable logistics services.

\section{CONCLUSIONS}

The conclusions in the study are as follows:

- E-Commerce Public Policy has a positive and significant effect on Online Purchasing Decisions.

- E-Commerce Technical Standards have a positive and significant effect on Online Purchasing Decisions.

- E-Commerce Organization System has a positive and significant influence on Online Purchasing Decisions.

\section{ACKNOWLEDGMENT}

This research is supported by Universitas Prof. Dr. Moestopo (Beragama) Jakarta, Universitas Teknologi Yogyakarta and Universitas Mercubuana, Jakarta.

\section{REFERENCES}

[1] H. Kartajaya, Positioning, Differentiation, and Brand. Jakarta: PT. Gramedia Main Library, 2004.

[2] Youngsters.id, Indonesia's E-Commerce Market Has the Largest Potential in Southeast Asia. [online]. Retrieved from http: //youngsters.id/. 2017.

[3] E. Turban, J. Outland, D. King, J.K. Lee, T.P. Liang, and D.C. Turban, Electronic commerce 2018: a managerial and social networks perspective. Springer, 2017.

[4] Schiffman and Kanuk, Consumer Behavior Edition 7. Jakarta: Index, 2008 .

[5] L. Agustino, Fundamentals of Public Policy. Bandung: Alfabeta, 2008.

[6] M. Suyanto, Advertising Strategies in E-Commerce of the World's Top Companies. Yogyakarta: Andi, 2003.

[7] C. Ahmadi, and D. Hermawan, E-Business \& E-Commerce. Denpasar: Andi, 2013.

[8] E. Rernawan, Organization Culture, Organizational Culture in Economic and Business Perspectives. Bandung: Alfabeta, 2011.

[9] E. Turban, D. King, J. Lee, and D. Viehland, Electronic commerce: A managerial perspective 2002. Prentice Hall, 2002.

[10] Sugiyono, Qualitative Quantitative Research Methods and R\&D Edition 13. Bandung: Alfabeta, 2011.

[11] C. Trihendradi, Easy Steps to Perform Statistical Analysis Using SPSS 19. Yogyakarta: Andi, 2011.

[12] I. Ghozali, Analysis With SPSS Advanced Multivariate first edition. Semarang: BP UNDIP, 2006. respondents led to the organization system of e-commerce that is either of them is a partner in e-commerce is e-commerce that 